\title{
Effectiveness of Training Clinicians' Communication Skills on Patients' Clinical Outcomes: A Systematic Review
}

\author{
Vinicius C. Oliveira, PhD, ${ }^{a}$ Manuela L. Ferreira, PhD, ${ }^{b}$ Rafael Z. Pinto, PhD, ${ }^{c}$ Ruben F. Filho, PhD, ${ }^{d}$ \\ Kathryn Refshauge, PhD, ${ }^{e}$ and Paulo H. Ferreira, PhD $^{f}$
}

\begin{abstract}
Objective: The aim of this systematic review was to investigate the literature on the effectiveness of communication skills training for clinicians on patients' clinical outcomes in primary care and rehabilitation settings.

Methods: We systematically reviewed the literature for randomized controlled trials investigating the effectiveness of communication skills training for clinicians on patients' satisfaction with care and on pain and disability in primary care and rehabilitation settings. The search strategy was conducted using AMED, PsycINFO, MEDLINE, CINAHL, EMBASE, PEDro, and Cochrane Central Register of Controlled Trials through June 2015. Methodological quality of included trials was assessed by 2 independent investigators using the PEDro scale, and consensus was used to resolve disagreements. Data were extracted, and meta-analyses were performed.

Results: Nineteen randomized controlled trials were included. Of these, 16 investigated communication training for clinicians that emphasized patient participation (eg, shared decision-making approaches). Communication training had small effects on patients' satisfaction with care when compared to control (4.1 points on a 100-point scale, $95 \%$ confidence interval [CI], 1.1-7.0). Communication training also had small effects on pain and disability with pooled results showing weighted mean differences of -3.8 points $(95 \% \mathrm{CI},-6.5$ to -1.1$)$ and $-3.6(95 \% \mathrm{CI},-5.4$ to -1.7$)$, respectively.

Conclusions: Studies show that communication training for clinicians produces small effects in improving patients' satisfaction with care or reducing pain and disability in primary care and rehabilitation settings. (J Manipulative Physiol Ther 2015;38:601-616)

Key Indexing Terms: Communication; Professional-Patient Relations; Review Literature as Topic
\end{abstract}

\footnotetext{
${ }^{\mathrm{a}}$ Research Fellow, Departamento de Fisioterapia, Universidade Federal de Minas Gerais, Belo Horizonte, Brazil.

b Research Fellow, The George Institute for Global Health, University of Sydney, Sydney, Australia.

${ }^{\mathrm{c}}$ Lecturer, Faculdade Ciências e Tecnologia, Universidade Estadual Paulista, Sao Paolo, Brazil.

${ }^{d}$ Professor, Faculdade Ciências e Tecnologia, Universidade Estadual Paulista, Sao Paolo, Brazil.

e Professor, Faculty of Health Sciences, University of Sydney, Sydney, Australia.

${ }_{\mathrm{f}}$ Senior Lecturer, Faculty of Health Sciences, University of Sydney, Sydney, Australia.

Submit requests for reprints to: Vinicius C Oliveira, $\mathrm{PhD}$, Departamento de Fisioterapia $3^{\circ}$ andar-Escola de Educação Física, Fisioterapia e Terapia Ocupacional-Universidade Federal de Minas Gerais (UFMG), Av Antônio Carlos 6627 Pampulha Belo Horizonte, MG, Brazil CEP: 31270-901.

(e-mail: viniciuscunhaoliveira@yahoo.com.br).

Paper submitted December 19, 2014; in revised form June 15, 2015; accepted June 15, 2015.

0161-4754

Copyright (C) 2015 by National University of Health Sciences. http://dx.doi.org/10.1016/j.jmpt.2015.08.002
}

$\Delta$ pproaches used by clinicians to communicate with patients during clinical encounters are essential to exchange information and increase clarity, resulting in greater adherence with rehabilitation programs. ${ }^{1,2} \mathrm{~A}$ complex pathway has suggested that training clinicians' communication skills on, for instance, shared decision making $^{3}$ could optimize their approaches and lately impact on improvements of patients' clinical outcomes. ${ }^{4}$ In approaches such as shared decision making, clinicians value patients' participation as well as their needs and preferences during clinical encounters. ${ }^{2}$ Therefore, clinicians' communication skills training could be imperative in the process of managing and altering clinicians' behaviors and to improve patients' outcomes in primary care and rehabilitation settings. ${ }^{5}$

The current knowledge on the relationship between clinicians' communication skills and improvements in patients' outcomes suggests the importance of communication training. ${ }^{6-9}$ For instance, communication skills used by clinicians during their interaction with patients are 
associated with better symptom resolution, functional and physiologic status, emotional health, and patients' satisfaction with care. ${ }^{6-9}$ Higher levels of therapeutic alliance, meaning more positive patient-clinician interaction, associate with greater improvements in clinical outcomes such as decreased pain and disability in chronic conditions. ${ }^{10}$ However, variables that are thought to be mediators in the process toward patients' clinical outcomes, including clinicians' communication skills, are complex, and whether training clinicians' communication skills in approaches such as shared decision making is effective to improve these patients' outcomes is still unclear.

Previous systematic reviews in oncology ${ }^{11,12}$ and in allied health ${ }^{4}$ have reported inconclusive evidence of the effectiveness of clinicians' communication skill training on patients' distress and satisfaction with care. Inconclusive evidence from these reviews ${ }^{4,11,12}$ was limited by the inclusion of low-quality studies (ie, nonrandomized controlled trials). No comprehensive review of high-quality studies (ie, randomized controlled trials) has investigated the effectiveness of clinicians' communication training on patients' satisfaction with care, pain, and disability in primary care and rehabilitation settings. Patients' satisfaction with care, pain, and disability are common clinical outcomes in primary care and rehabilitation settings, ${ }^{13}$ and their investigation may impact on the use and design of future approaches used by clinicians during patient-clinician interactions. Summarizing the evidence from high-quality studies in a systematic way is timing. Such an investigation may contribute to the understanding of the complex pathway between clinicians' communication skills and patients' outcomes.

The aim of this review was to investigate whether communication skills training for clinicians is effective on patients' clinical outcomes of patients' satisfaction with care, pain, and disability in primary care and rehabilitation settings.

\section{MeTHODS}

\section{Identification of Studies}

The search strategy was conducted using AMED, PsycINFO, MEDLINE, CINAHL, EMBASE, PEDro, and Cochrane Central Register of Controlled Trials. The full search strategy conducted on November 2012 and updated on June 2015 is presented in Appendix A.

Several criteria were used to select eligible studies. We included randomized controlled trials that investigated the effect of any communication training (eg, patient-centered and shared decision-making approaches) for primary care and/or rehabilitation clinicians (eg, chiropractors, physiotherapists, osteopaths, doctors, residents, nurses, occupational therapists, and speech pathologists) compared to control (ie, no intervention or minimal communication intervention) on patients' satisfaction with care, pain intensity, and disability. Trials of mental illness were excluded because the nature of care for mental illness differs from conventional consultations.
Searches were not restricted for language. Screening of titles, abstracts, and full text identified in the search was undertaken by 2 investigators (VCO and RFF) using the eligibility criteria outlined above. Any disagreement was resolved by consensus.

\section{Assessment of Methodological Quality}

Methodological quality of included trials was assessed by 2 independent investigators (VCO and RZP) using the PEDro scale (score ranging from 0 to 10$),{ }^{14}$ and consensus was used to resolve disagreements.

\section{Data Analysis}

Descriptive data were extracted on clinicians and patients (ie, total sample, source of participants, age, gender, and treatment comparisons). Means and SDs were extracted for patients' satisfaction with care, pain, and disability. Where necessary, outcome scores (ie, mean and SDs) were transformed to common 100-point scales to compare trials. SDs were not provided in 6 trials, and values were either calculated based on the confidence intervals ${ }^{15-17}$ or inputted from the average SD of other included trials ${ }^{18-20}$ according to the Cochrane Collaboration recommendations. ${ }^{21}$

Outcome data were extracted for short-term follow-up $(<6$ months after randomization). When multiple follow-up data were reported within the time point defined in our review, the follow-up closer to the end of intervention was used.

Data were pooled in meta-analyses and described as weighted mean differences with $95 \%$ confidence intervals. Between-trial heterogeneity was assessed using $I^{2}$ statistics, and random-effects models were used where appropriate (ie, an $I^{2}$ of $\left.\geq 50 \%\right){ }^{21}$ To judge the magnitude of communication training effects (differences between training and control groups at follow-up), we used definitions of the American College of Physicians and the American Pain Society, ${ }^{22}$ as follows: small to moderate effects $(<20$ points on a 100 -point scale) and large effects ( $>20$ points). A funnel plot of SE by difference in means was used to investigate publication bias where appropriate and Comprehensive Meta-Analysis software version 2.2.04 (Biostat, Englewood, NJ) was used to conduct all analyses.

The Grading of Recommendations Assessment, Development and Evaluation (GRADE) system was used to summarize the overall quality of the evidence. ${ }^{23}$ The 4 levels of the GRADE system range from high-quality evidence, where further research is very unlikely to change the estimate of prevalence, to very low-quality evidence, where the estimate of prevalence is very uncertain. ${ }^{23}$ Scoring the quality of evidence for each outcome using GRADE started at high-quality evidence, which was downgraded by 1 point if one of the following criteria was present: (i) methodological quality score of less than 5 points of 10 , (ii) inconsistency of estimates among trials, (iii) indirectness of participants selected by no reliable methods (eg, findings on imaging), (iv) imprecision for 

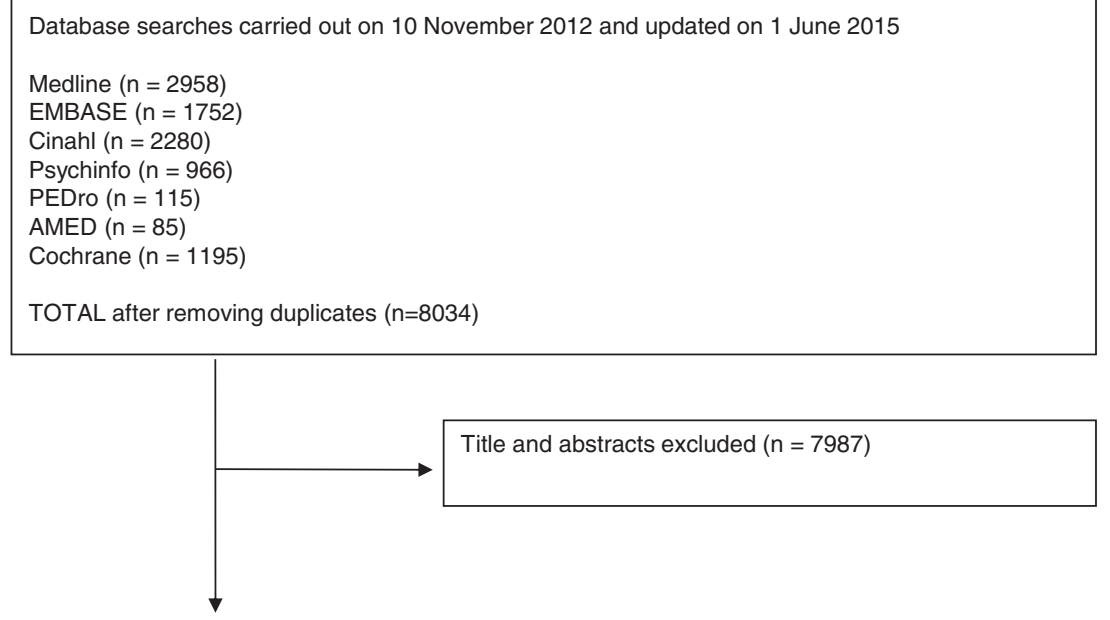

47 Potentially eligible after assessing titles and abstracts

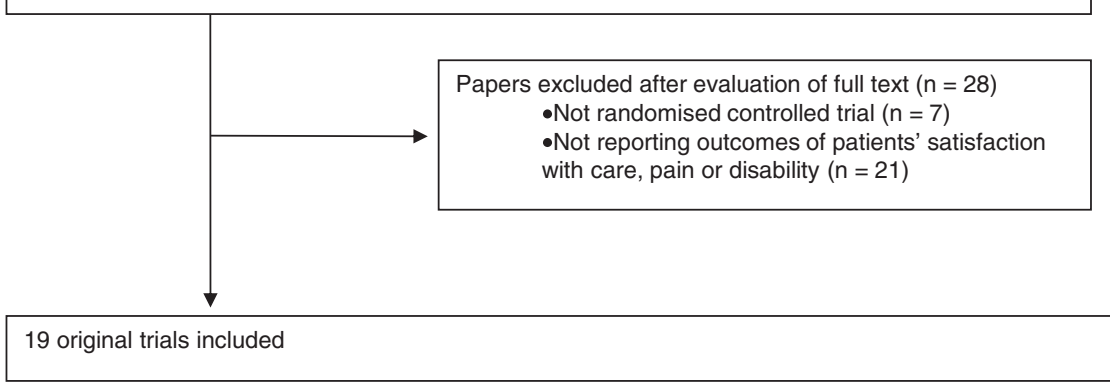

Fig I. Flowchart of the study selection process. AMED, Alled and Complementary Medicine Database; Cinahl, Cumulative Index to Nursing and Allied Health Literature; EMBASE, Excerpta Medica database; PEDro, Physiotherapy Evidence Database.

samples less than 300 participants for each outcome, ${ }^{24}$ and (v) publication bias for each outcome or when its analysis was not possible due to small number of trials. ${ }^{25}$ Two independent reviewers (VCO and RZP) independently assessed the quality of the evidence using GRADE, and disagreements were resolved using consensus.

The protocol for this systematic review was registered at PROSPERO (CRD42012002120) and is available at: http:// www.crd.york.ac.uk/PROSPERO.

\section{RESULTS}

Search strategies identified 8034 titles after removing duplicates. Screening of titles and abstracts identified 47 potentially eligible articles and 19 original trials were included. ${ }^{15-20,26-38}$ The main reasons for excluding articles from the 47 potentially eligible articles were as follows: the study was not randomized $(\mathrm{n}=7)$ and the study did not report outcomes of patients' satisfaction with care, pain, or disability $(\mathrm{n}=21)($ Fig 1).

\section{Characteristics of Included Trials}

Included trials recruited 1036 clinicians treating 9063 patients with musculoskeletal problems ${ }^{29,31,33,36,38}$ or other conditions such as cancer ${ }^{15-20,26-28,30,32,34,35,37}$ (Table 1). Eighteen trials investigated the effects of training on patients' satisfaction with care ${ }^{15-20,26-30,32-38}$ and 2 trials investigated effects on pain ${ }^{31,38}$ and disability. ${ }^{31,38}$

\section{Current Communication Skills Training for Clinicians}

Sixteen of 19 trials focused on communication training that emphasized patient's participation (eg, patient-centered and shared decision-making approaches) ${ }^{15-20,26-32,34,35,37}$ (Table 2). Trials used theoretical workshops, written information, and discussion sessions with audiovisual resources (ie, audiotape or videotape of clinical consultations) as communication training. The number of intervention sessions given by trained people varied from 1 to 12 within 1 day to 6 months, and some interventions used reinforcement sessions.

\section{Assessment of Methodological Quality}

The mean score for methodological quality was 4.9/10 (ranging from 3 to 7) on PEDro scale. The methodological issues included the following: absence of concealed allocation; absence of report of similar groups at baseline; blinding of clinicians, patients, and assessors; more than $15 \%$ dropouts; 
Table I. Descriptive Data of Included Trials $(n=19)$

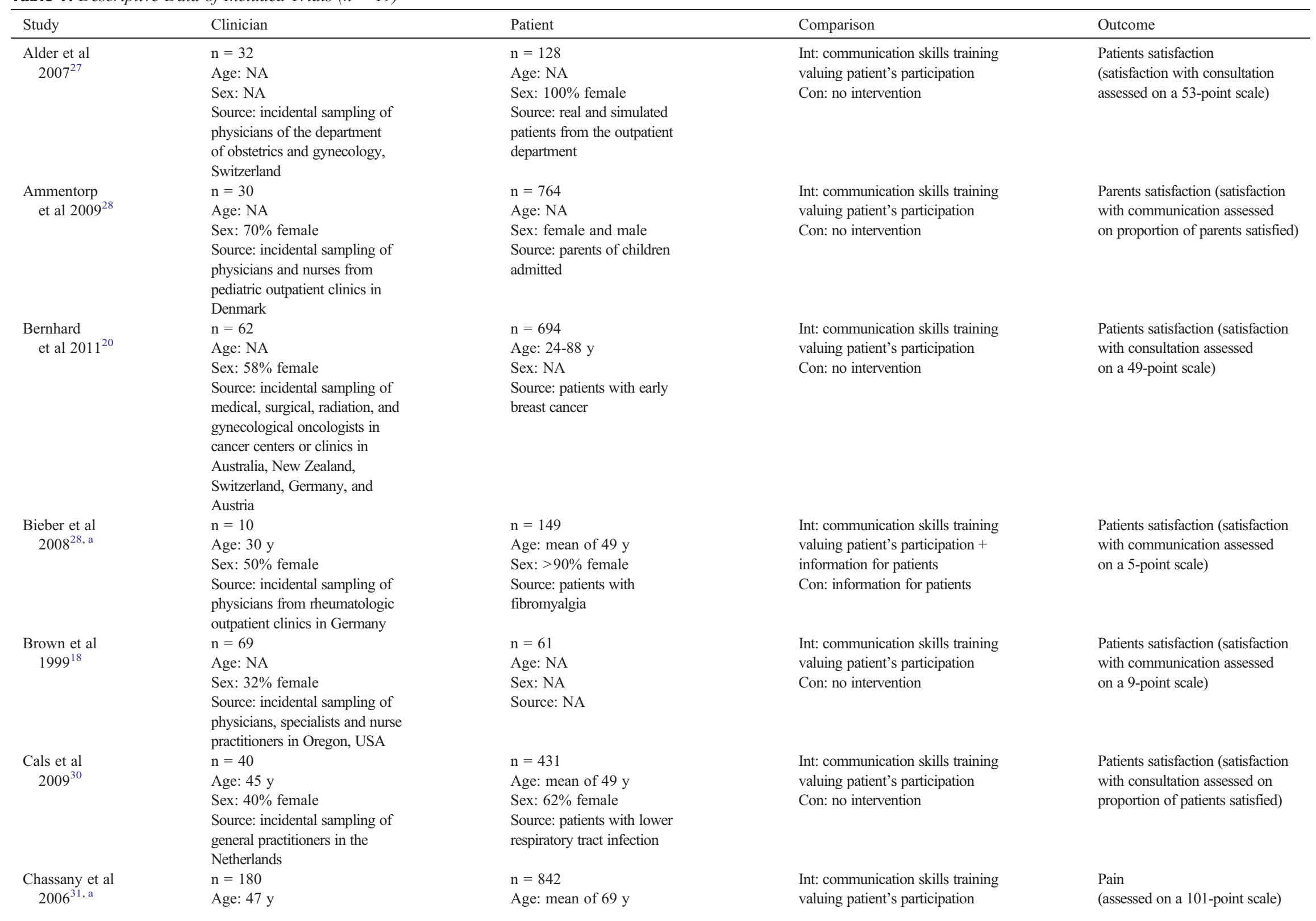


Sex: NA

Source: random sampling of general practitioners

Edwards et a $2004^{15}$

$\mathrm{n}=21$

Age: 38 y

Sex: $40 \%$ female

Source: incidental sampling of

general practitioners in Gwent,

South Wales

$\begin{array}{cl}\text { Evans et al } & \mathrm{n}=52 \\ 1987^{32} & \text { Age: } 41 \mathrm{y} \\ & \text { Sex: } 0 \% \text { female } \\ & \text { Source: random sampling of } \\ & \text { general practitioners in } \\ & \text { Melbourne, Australia } \\ \text { Frostholm et al } & \mathrm{n}=38 \\ 2005^{33, \text { a }} & \text { Age: NA } \\ & \text { Sex: NA } \\ & \text { Source: incidental sampling of } \\ & \text { physicians in Aarhus County, } \\ & \text { Denmark } \\ & \mathrm{n}=80 \\ \text { Haskard et al } & \text { Age: } 37 \mathrm{y} \\ 2008^{19} & \text { Sex: } 37 \% \text { female } \\ & \text { Source: incidental sampling of } \\ & \text { physicians from primary care } \\ & \text { specialties } \\ & \mathrm{n}=72 \\ & \text { Age: } 41 \mathrm{y} \\ \text { Jensen } & \text { Sex: } 35 \% \text { female } \\ \text { et al } 2011^{16} & \text { Source: incidental sampling of } \\ & \text { physicians from a large general } \\ & \text { teaching hospital in Norway } \\ & \mathrm{n}=19 \text { sites } \\ \text { Lewis et al } & \text { Age: NA } \\ \text { Kennedy et al } & \text { Sex: NA } \\ 2004^{26} & \text { Source: incidental sampling of } \\ & \text { clinicians of outpatient clinics } \\ & \text { at hospitals in England } \\ \mathrm{n}=56 \\ \text { Age: } 29 \mathrm{y} \\ \text { Sex: } 50 \% \text { female } \\ \text { Source: incidental sampling of } \\ \text { pediatric trainees and residents } \\ \end{array}$

Sex: $65 \%$ female

Source: patients with

osteoarthritis

$\mathrm{n}=353$

Age: mean of 59 y

Sex: $59 \%$ female

Source: patients with nonvalvular

atrial fibrillation, prostatism,

menorrhagia, and

menopause-related problems

attending consultation for review

$\mathrm{n}=400$

Age: mean of $42 \mathrm{y}$

Sex: $55 \%$ female

Source: real patients attended

$\mathrm{n}=1785$

Age: mean of $39 \mathrm{y}$

Sex: $62.4 \%$ female

Source: patients with

functional disorders

and somatization

$\mathrm{n}=80$

Age: NA

Sex: $<50 \%$ female

Source: patients interacting

with physicians

$\mathrm{n}=72$

Age: NA

Sex: NA

Source: patients

consecutively attended

$\mathrm{n}=635$

Age: means around $44 \mathrm{y}$

Sex: $52 \%$ female

Source: patients who had

established ulcerative

colitis or Crohn disease

$\mathrm{n}=141$

Age: means around $8 \mathrm{y}$

Sex: $43 \%$ female

Source: 6- to 17-year-old

patients accompanied

by an adult
Con: presentation about patient

recruitment

Int: communication skills training valuing patient's participation

Con: no intervention

Int: communication skills training valuing patient's participation

Con: no intervention

Int: communication skills training

that do not focus on

patient's participation

Con: no intervention

Int: communication skills training valuing patient's participation

Con: no intervention

Int: communication skills training valuing patient's participation

Con: no intervention (crossover)

Int: communication skills training valuing patient's participation

Con: no intervention

Int: communication skills training valuing patient's participation

Con: no intervention
Disability

(assessed on a 97-point scale)

Patients satisfaction (satisfaction with communication assessed on a 101-point scale)

Patients satisfaction (satisfaction with consultation on a 100-point scale)

Patients satisfaction (satisfaction with consultation assessed

on a 35-point scale)

Patients satisfaction (satisfaction with consultation assessed on a 5-point scale)

Patients satisfaction (satisfaction with consultation assessed on a 11-point scale)

Patients satisfaction (satisfaction with consultation assessed on a 91-point scale)

Patients satisfaction (satisfaction with consultation assessed on a 4-point scale) 
Table I (continued)

\begin{tabular}{|c|c|c|c|c|}
\hline Study & Clinician & Patient & Comparison & Outcome \\
\hline $\begin{array}{r}\text { Loh et al } \\
2007^{35}\end{array}$ & $\begin{array}{l}\mathrm{n}=30 \\
\text { Age: } 48 \text { y } \\
\text { Sex: } 27 \% \text { female } \\
\text { Source: incidental sampling of } \\
\text { primary care physicians in } \\
\text { Germany }\end{array}$ & $\begin{array}{l}\mathrm{n}=405 \\
\text { Age: range from } 40.8-50.4 \mathrm{y} \\
\text { Sex: females ranged } \\
\text { from } 65.3 \%-77.8 \% \\
\text { Source: patients with newly } \\
\text { diagnosed depression }\end{array}$ & $\begin{array}{l}\text { Int: communication skills training } \\
\text { valuing patient's participation } \\
\text { Con: no intervention }\end{array}$ & $\begin{array}{l}\text { Patients satisfaction (satisfaction } \\
\text { with consultation assessed } \\
\text { on a } 25 \text {-point scale) }\end{array}$ \\
\hline $\begin{array}{l}\text { Sheffer } \\
\qquad 1999^{36, \text { a }}\end{array}$ & $\begin{array}{l}\mathrm{n}=54 \\
\text { Age: NA } \\
\text { Sex: NA } \\
\text { Source: incidental sampling of } \\
\text { family practice residents in } \\
\text { Chicago }\end{array}$ & $\begin{array}{l}\mathrm{n}=54 \\
\text { Age: } 31 \text { y } \\
\text { Sex: } 70 \% \text { female } \\
\text { Source: patients over } \\
\text { 18-year-old suffering } \\
\text { musculoskeletal disorders }\end{array}$ & $\begin{array}{l}\text { Int: communication skills training } \\
\text { that do not focus on patient's } \\
\text { participation } \\
\text { Con: no intervention }\end{array}$ & $\begin{array}{l}\text { Patients satisfaction (satisfaction } \\
\text { with consultation assessed } \\
\text { on a } 7 \text {-point scale) }\end{array}$ \\
\hline $\begin{array}{l}\text { Shilling et al } \\
2003^{37}\end{array}$ & $\begin{array}{l}\mathrm{n}=160 \\
\text { Age: NA } \\
\text { Sex: NA } \\
\text { Source: incidental sampling of } \\
\text { oncologists in UK }\end{array}$ & $\begin{array}{l}\mathrm{n}=861 \\
\text { Age: } 86.4 \% \geq 40 \mathrm{y} \\
\text { Sex: } 61.3 \% \text { female } \\
\text { Source: patients attending } \\
\text { oncologists }\end{array}$ & $\begin{array}{l}\text { Int: communication skills training } \\
\text { valuing patient's participation } \\
\text { Con: no intervention }\end{array}$ & $\begin{array}{l}\text { Patients satisfaction (satisfaction } \\
\text { with consultation assessed } \\
\text { on a } 64 \text {-point scale) }\end{array}$ \\
\hline $\begin{array}{l}\text { Suarez-Almazor } \\
\text { et al } 2010^{38, a}\end{array}$ & $\begin{array}{l}\mathrm{n}=6 \\
\text { Age: NA } \\
\text { Sex: } 0 \% \text { female } \\
\text { Source: incidental sampling of } \\
\text { Chinese acupuncturists recruited } \\
\text { through the American College of } \\
\text { Acupuncture and Oriental Medicine }\end{array}$ & $\begin{array}{l}\mathrm{n}=560 \\
\text { Age: means around } 63 \mathrm{y} \\
\text { Sex: } 64 \% \text { female } \\
\text { Source: patients with } \\
\text { knee osteoarthritis }\end{array}$ & $\begin{array}{l}\text { Int: acupuncture }+ \text { communication } \\
\text { skills training that do not focus } \\
\text { on patient's participation } \\
\text { Con: acupuncture }\end{array}$ & $\begin{array}{l}\text { Patients satisfaction (satisfaction } \\
\text { with consultation assessed } \\
\text { on a 5-point scale) } \\
\text { Pain } \\
\text { (assessed on a 101-point scale) } \\
\text { Disability } \\
\text { (assessed on a 101-point scale) }\end{array}$ \\
\hline $\begin{array}{l}\text { Wetzels et al } \\
2005^{17}\end{array}$ & $\begin{array}{l}\mathrm{n}=25 \\
\text { Age: NA } \\
\text { Sex: NA } \\
\text { Source: incidental sampling of } \\
\text { general practitioners in the } \\
\text { Netherlands }\end{array}$ & $\begin{array}{l}\mathrm{n}=648 \\
\text { Age: means around } 76 \mathrm{y} \\
\text { Sex: } 33 \% \text { female } \\
\text { Source: patients } \geq 70 \mathrm{y}\end{array}$ & $\begin{array}{l}\text { Int: communication skills training } \\
\text { valuing patient's participation } \\
\text { Con: no intervention }\end{array}$ & $\begin{array}{l}\text { Patients satisfaction (satisfaction } \\
\text { with communication assessed } \\
\text { on a 4-point scale) }\end{array}$ \\
\hline
\end{tabular}

Patients satisfaction, highest scores for best satisfaction with care; $y$, mean/median age in years.

${ }^{a}$ Musculoskeletal area. 
Table 2. Communication Skills Training of Included Trials $(n=19)$

\begin{tabular}{|c|c|c|}
\hline Study & Communication Training & $\begin{array}{l}\text { No. of } \\
\text { Sessions }\end{array}$ \\
\hline $\begin{array}{c}\text { Alder et al } \\
2007^{27}\end{array}$ & $\begin{array}{l}\text { Training aimed patient-centered approach from a biopsychosocial perspective establishing therapeutic relationship to exchange } \\
\text { information and educate patients and to encourage shared decision making. One-day workshop gave clinicians the theoretical } \\
\text { background for the consultations and the communicative and interpersonal processes. The theoretical background of } \\
\text { communication, different communication models, and general and specific communication skills were discussed. Three } \\
\text { half-day practice seminars were held for small groups where the acquired knowledge and specific communication skills were } \\
\text { practiced (with video feedback). The last part of the intervention consisted of 5-6 1-h supervision sessions for each clinician } \\
\text { over 3-months period. Trainees discussed problems related to types of communication they have encountered in their clinical } \\
\text { work and were supervised by the group and the trainer. Short communication sequences were practiced. }\end{array}$ & $9-10$ \\
\hline $\begin{array}{l}\text { Ammentorp } \\
\text { et al } 2009^{28}\end{array}$ & $\begin{array}{l}\text { Training consisted of } 2 \text { sections lasting, respectively, } 3 \text { and } 2 \text { days with } 4 \text { weeks separating sections. In between, clinicians } \\
\text { videotaped one of their own consultations, and videotapes were used to provide feedback during the second section of the } \\
\text { course. The training focused on the patient-centered approach eliciting and understanding patient concerns and needs and } \\
\text { reaching a shared understanding of the problem and its treatment. }\end{array}$ & 5 \\
\hline $\begin{array}{l}\text { Bernhard et al } \\
2011^{20}\end{array}$ & $\begin{array}{l}\text { Training consisted of a 7-h workshop with 1-2 follow-up telephone calls over } 2 \text { mo. The training focused on shared decision } \\
\text { making and used video modeling behavior. Before the workshop, clinicians were expected to have read the strategies } \\
\text { document. For each clinician, } 2 \text { audiotaped consultations were analyzed, and feedback was provided at the end of the } \\
\text { workshop. One month later, the trainer called the clinicians to reinforce and extend learning. }\end{array}$ & $2-3$ \\
\hline $\begin{array}{r}\text { Bieber et al } \\
2008^{28, a}\end{array}$ & $\begin{array}{l}\text { Training aimed to ameliorate clinician's patient-centered communication to perform shared decision making. The training } \\
\text { consisted of } 12 \text { sessions of } 1.5 \mathrm{~h} \text {. It focused on practicing competencies needed for the shared decision-making process } \\
\text { and on building a good working alliance with the patient. Interactive talks and role plays are used, and videos are analyzed. } \\
\text { Sensitivity to deliberate and unconscious signals of verbal and nonverbal communications is trained. Specific steps in } \\
\text { shared decision making are practiced: inviting patients explicitly into the decision-making process, checking patients' role } \\
\text { preference, explaining the notion of medical equipoise and available treatment options, checking patients' understanding and } \\
\text { further need for information, identifying and responding to any expectations and fears, and negotiating a treatment decision. }\end{array}$ & 12 \\
\hline $\begin{array}{c}\text { Brown et al } \\
1999^{18}\end{array}$ & $\begin{array}{l}\text { Training consisted of an initial 4-h group workshop, } 2 \mathrm{~h} \text { of subsequent homework, and a 4-h follow-up workshop. } \\
\text { The first workshop focused on skills for building effective relationships with patients including: listening actively; responding } \\
\text { to patients' feelings; and communicating concern, understanding, and respect. The second workshop focused on skills for } \\
\text { successful negotiation, particularly in situations of disagreement. During a 1-mo interval between the } 2 \text { workshops, the } \\
\text { clinicians were asked to audiotape their consultations and listen to the recordings. In addition, an instructor called clinicians } \\
\text { during the interval for reinforcement. The workshops included didactic components related to clinical needs and role playing } \\
\text { that allowed clinicians to practice communication skills while focusing on situations that they found challenging and relevant. } \\
\text { Instructors taught interactively, encouraging dialogue with and among participants. }\end{array}$ & 3 \\
\hline $\begin{array}{l}\text { Cals et al } \\
2009^{30}\end{array}$ & $\begin{array}{l}\text { Training based on patient-centered strategy to achieve shared decisions about investigation and treatment. The training } \\
\text { involved a 2-h group seminar, preceded and followed by consulting with simulated patients. The training was based on the } \\
\text { elicit-provide-elicit framework, where clinicians first elicit what the patients know about their condition and what the patients' } \\
\text { main worries and expectations are. Later, clinicians provide information relevant to the patients' individual understanding and } \\
\text { interest. Then, clinicians elicit the patients' interpretation about what has been said and done and discuss implications. } \\
\text { Clinicians had the opportunity to use the enhanced communication skills in daily practice during } 8 \text { wk before inclusion } \\
\text { for study and had feedback from simulated patients. }\end{array}$ & 1 \\
\hline $\begin{array}{c}\text { Chassany et al } \\
2006^{31, a}\end{array}$ & $\begin{array}{l}\text { Pragmatic and interactive training based on patient-physician relationship and on biopsychosocial model. The training focused } \\
\text { on } 3 \text { themes: workshop } 1 \text { dealt with the patient-physician relationship; workshop } 2 \text { covered the analysis and evaluation of pain; } \\
\text { and workshop } 3 \text { was dedicated to prescribing and the negotiation of a therapeutic contract with the patient. Videos of } \\
\text { consultations and clinical situations were used to generate reactions and reflection from clinicians. The group training was } \\
\text { delivered to clinicians during a 4-h meeting by } 3 \text { pairs of trainers acting as facilitator and expert. Each pair of trainers trained } \\
\text { a group who discussed issues in groups of } 6 \text {. After the training, } 8 \text { reminders were mailed to clinicians. }\end{array}$ & 9 \\
\hline $\begin{array}{l}\text { Edwards et al } \\
2004^{15}\end{array}$ & $\begin{array}{l}\text { Training workshops used simulated patients to develop shared decision-making competences. The competences involved: } \\
\text { clear specification of condition; equipoise professionals may not have a clear preference about which treatment option is the } \\
\text { best; treatment options; identify patients' preferences; check understanding of the range of options and information provided; } \\
\text { explore ideas, concerns, and expectations; check role preference that patients accept the process and identify their } \\
\text { decision-making role preference; decision making involving the patient to the extent they desire to be involved; review } \\
\text { treatment needs and preferences; and the decision. }\end{array}$ & NA \\
\hline $\begin{array}{c}\text { Evans et al } \\
1987^{32}\end{array}$ & $\begin{array}{l}\text { Two 2-h group seminar covered communication deficiencies and suggested techniques for increasing patent satisfaction. } \\
\text { Written material provided for clinicians covered psychological variables in patient-clinician interactions, patient satisfaction, } \\
\text { recall and understanding, patient compliance, and techniques. Training focused on clinicians' awareness and knowledge of } \\
\text { potential communication problems in the consultation setting. At the first seminar, clinicians were given the written material } \\
\text { and rainer presented a 1-h lecture on patient satisfaction and compliance. The remaining time was spent in discussion within } \\
\text { the group. }\end{array}$ & 2 \\
\hline $\begin{array}{l}\text { Frostholm et al } \\
\qquad 2005^{33, a}\end{array}$ & $\begin{array}{l}\text { Training consisted of an educational program on assessment, treatment, and management of somatization, which rests on } \\
\text { present theoretical and scientific knowledge about somatization and adopts a cognitive oriented approach. The training took } \\
\text { place in the month preceding the study and consisted of a 2-d residential course }(16 \mathrm{~h}) \text { followed by } 3-4 \text { evening courses } \\
(2 \text { hours' duration each). Moreover, a booster meeting }(2 \mathrm{~h}) \text { after } 3 \text { months and a facilitator visit to the physician's practice }\end{array}$ & $7-8$ \\
\hline
\end{tabular}


Table 2 (continued)

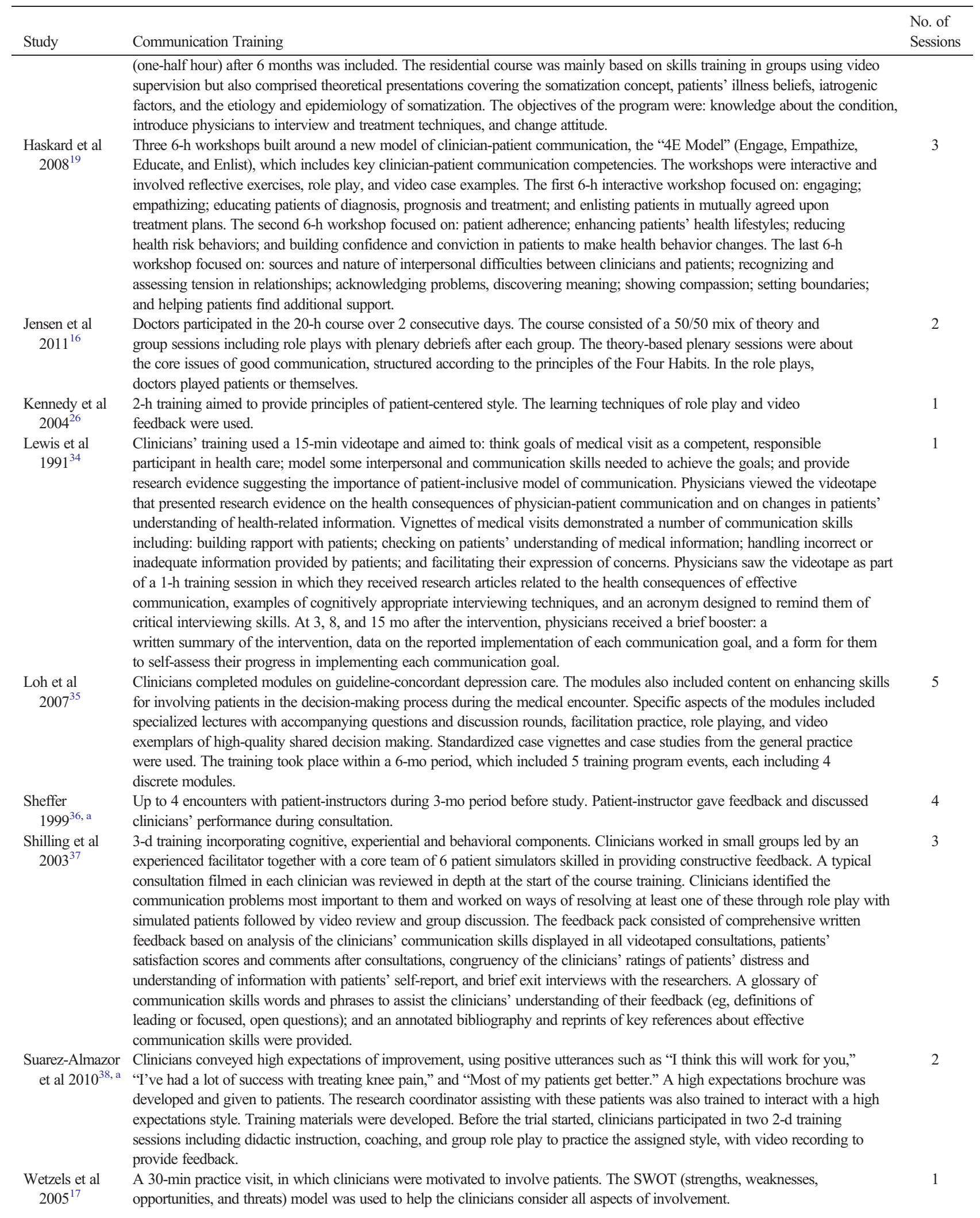

$N A$, not available.

${ }^{\text {a }}$ Musculoskeletal area. 
Table 3. PEDro Scores of Included Trials $(n=19)$

\begin{tabular}{|c|c|c|c|c|c|c|c|c|c|c|c|}
\hline Study & $\begin{array}{l}\text { Random } \\
\text { Allocation }\end{array}$ & $\begin{array}{l}\text { Concealed } \\
\text { Allocation }\end{array}$ & $\begin{array}{l}\text { Groups } \\
\text { Similar at } \\
\text { Baseline }\end{array}$ & $\begin{array}{l}\text { Participant } \\
\text { Blinding }\end{array}$ & $\begin{array}{l}\text { Therapist } \\
\text { Blinding }\end{array}$ & $\begin{array}{l}\text { Assessor } \\
\text { Blinding }\end{array}$ & $\begin{array}{l}<15 \% \\
\text { Dropouts }\end{array}$ & $\begin{array}{l}\text { Intention- } \\
\text { to-Treat } \\
\text { Analysis }\end{array}$ & $\begin{array}{l}\text { Between- } \\
\text { Group } \\
\text { Difference }\end{array}$ & $\begin{array}{l}\text { Point } \\
\text { Estimate and } \\
\text { Variability }\end{array}$ & $\begin{array}{l}\text { Total } \\
(0-10)\end{array}$ \\
\hline $\begin{array}{l}\text { Alder et al } \\
2007^{27}\end{array}$ & $\mathrm{Y}$ & $\mathrm{N}$ & $\mathrm{Y}$ & $\mathrm{Y}$ & $\mathrm{N}$ & $\mathrm{Y}$ & $\mathrm{Y}$ & $\mathrm{N}$ & $\mathrm{Y}$ & $\mathrm{Y}$ & 7 \\
\hline $\begin{array}{l}\text { Ammentop et al } \\
2009^{28}\end{array}$ & $\mathrm{Y}$ & $\mathrm{Y}$ & $\mathrm{N}$ & $\mathrm{Y}$ & $\mathrm{N}$ & $\mathrm{Y}$ & $\mathrm{Y}$ & $\mathrm{N}$ & $\mathrm{Y}$ & $\mathrm{Y}$ & 7 \\
\hline $\begin{array}{l}\text { Bernhard et al } \\
2011^{20}\end{array}$ & $\mathrm{Y}$ & $\mathrm{N}$ & $\mathrm{Y}$ & $\mathrm{N}$ & $\mathrm{N}$ & $\mathrm{N}$ & $\mathrm{N}$ & $\mathrm{N}$ & $\mathrm{Y}$ & $\mathrm{N}$ & 3 \\
\hline $\begin{array}{c}\text { Bieber et al } \\
2008^{28}\end{array}$ & $\mathrm{Y}$ & $\mathrm{Y}$ & $\mathrm{N}$ & $\mathrm{Y}$ & $\mathrm{N}$ & $\mathrm{Y}$ & $\mathrm{N}$ & $\mathrm{Y}$ & $\mathrm{Y}$ & $\mathrm{Y}$ & 7 \\
\hline $\begin{array}{c}\text { Brown et al } \\
1999^{18}\end{array}$ & $\mathrm{Y}$ & $\mathrm{N}$ & $\mathrm{Y}$ & $\mathrm{N}$ & $\mathrm{N}$ & $\mathrm{N}$ & $\mathrm{Y}$ & $\mathrm{N}$ & $\mathrm{Y}$ & $\mathrm{Y}$ & 5 \\
\hline $\begin{array}{l}\text { Cals et al } \\
2009^{30}\end{array}$ & $\mathrm{Y}$ & $\mathrm{N}$ & $\mathrm{N}$ & $\mathrm{N}$ & $\mathrm{N}$ & $\mathrm{N}$ & $\mathrm{Y}$ & $\mathrm{Y}$ & $\mathrm{Y}$ & $\mathrm{Y}$ & 5 \\
\hline $\begin{array}{l}\text { Chassany et al } \\
2006^{31}\end{array}$ & $\mathrm{Y}$ & $\mathrm{N}$ & $\mathrm{Y}$ & $\mathrm{N}$ & $\mathrm{N}$ & $\mathrm{N}$ & $\mathrm{Y}$ & $\mathrm{Y}$ & $\mathrm{Y}$ & $\mathrm{Y}$ & 6 \\
\hline $\begin{array}{l}\text { Edwards et al } \\
2004^{15}\end{array}$ & $\mathrm{Y}$ & $\mathrm{N}$ & $\mathrm{N}$ & $\mathrm{N}$ & $\mathrm{N}$ & $\mathrm{N}$ & $\mathrm{N}$ & $\mathrm{N}$ & $\mathrm{Y}$ & $\mathrm{Y}$ & 3 \\
\hline $\begin{array}{c}\text { Evans et al } \\
1987^{32}\end{array}$ & $\mathrm{Y}$ & $\mathrm{N}$ & $\mathrm{N}$ & $\mathrm{N}$ & $\mathrm{N}$ & $\mathrm{N}$ & $\mathrm{Y}$ & $\mathrm{N}$ & $\mathrm{Y}$ & $\mathrm{Y}$ & 4 \\
\hline $\begin{array}{l}\text { Frostholm et al } \\
\qquad 2005^{33}\end{array}$ & $\mathrm{Y}$ & $\mathrm{N}$ & $\mathrm{N}$ & $\mathrm{N}$ & $\mathrm{N}$ & $\mathrm{N}$ & $\mathrm{N}$ & $\mathrm{N}$ & $\mathrm{Y}$ & $\mathrm{Y}$ & 3 \\
\hline $\begin{array}{l}\text { Haskard et al } \\
2008^{19}\end{array}$ & $\mathrm{Y}$ & $\mathrm{N}$ & Y & $\mathrm{N}$ & $\mathrm{N}$ & $\mathrm{N}$ & $\mathrm{Y}$ & $\mathrm{N}$ & $\mathrm{Y}$ & $\mathrm{Y}$ & 5 \\
\hline $\begin{array}{l}\text { Jensen et al } \\
2011^{16}\end{array}$ & $\mathrm{Y}$ & $\mathrm{N}$ & $\mathrm{Y}$ & $\mathrm{N}$ & $\mathrm{N}$ & $\mathrm{Y}$ & $\mathrm{N}$ & $\mathrm{Y}$ & $\mathrm{Y}$ & $\mathrm{Y}$ & 6 \\
\hline $\begin{array}{l}\text { Kennedy et al } \\
2004^{26}\end{array}$ & $\mathrm{Y}$ & $\mathrm{N}$ & $\mathrm{Y}$ & $\mathrm{N}$ & $\mathrm{N}$ & $\mathrm{N}$ & $\mathrm{N}$ & $\mathrm{Y}$ & $\mathrm{Y}$ & $\mathrm{Y}$ & 5 \\
\hline $\begin{array}{c}\text { Lewis et al } \\
1991^{34}\end{array}$ & $\mathrm{Y}$ & $\mathrm{N}$ & $\mathrm{N}$ & $\mathrm{N}$ & $\mathrm{N}$ & $\mathrm{N}$ & $\mathrm{N}$ & $\mathrm{N}$ & $\mathrm{Y}$ & $\mathrm{Y}$ & 3 \\
\hline Loh et al $2007^{35}$ & $\mathrm{Y}$ & $\mathrm{Y}$ & $\mathrm{Y}$ & $\mathrm{N}$ & $\mathrm{N}$ & $\mathrm{N}$ & $\mathrm{N}$ & $\mathrm{N}$ & $\mathrm{Y}$ & $\mathrm{Y}$ & 5 \\
\hline Sheffer $1999^{36}$ & $\mathrm{Y}$ & $\mathrm{N}$ & $\mathrm{N}$ & $\mathrm{N}$ & $\mathrm{N}$ & $\mathrm{N}$ & $\mathrm{N}$ & $\mathrm{N}$ & $\mathrm{Y}$ & Y & 3 \\
\hline $\begin{array}{l}\text { Shilling et al } \\
2003^{37}\end{array}$ & $\mathrm{Y}$ & $\mathrm{N}$ & $\mathrm{N}$ & $\mathrm{N}$ & $\mathrm{N}$ & $\mathrm{N}$ & $\mathrm{N}$ & $\mathrm{N}$ & $\mathrm{Y}$ & $\mathrm{Y}$ & 3 \\
\hline $\begin{array}{l}\text { Suarez-Almazor } \\
\text { et al } 2010^{38}\end{array}$ & $\mathrm{Y}$ & $\mathrm{Y}$ & $\mathrm{Y}$ & $\mathrm{N}$ & $\mathrm{N}$ & $\mathrm{N}$ & $\mathrm{Y}$ & $\mathrm{Y}$ & $\mathrm{Y}$ & $\mathrm{Y}$ & 7 \\
\hline $\begin{array}{l}\text { Wetzels et al } \\
2005^{17}\end{array}$ & $\mathrm{Y}$ & Y & Y & $\mathrm{N}$ & $\mathrm{N}$ & $\mathrm{N}$ & $\mathrm{N}$ & $\mathrm{Y}$ & $\mathrm{Y}$ & $\mathrm{Y}$ & 6 \\
\hline TOTAL & 19 & 5 & 10 & 3 & 0 & 4 & 8 & 7 & 19 & 18 & $4.9 / 10$ \\
\hline
\end{tabular}

$N$, no; $Y$, yes.

absence of an intention-to-treat analysis; and absence of report of point estimates and variability (Table 3 ).

\section{Effectiveness of Communication Skills Training for Clinicians on Patients' Satisfaction With Care, Pain, and Disability}

Figures 2 and 3 show meta-analyses for patients' satisfaction with care and pain and disability, respectively. Appendix B shows extracted data transformed and imputations (ie, means, SDs, and sample size for the included trials).

Satisfaction With Care. Pooled data of the 16 comparisons from 15 original trials provided weighted mean difference for patients' satisfaction with care of 4.1 points ( $95 \%$ confidence interval [CI], 1.1-7.0) on a 100-point scale (Fig 2). Publication bias was not detected (Fig 4). According to the GRADE system used in this review to interpret the results, there is low-quality evidence that clinicians' communication training has small but statistically significant effects when compared to control interventions on patients' satisfaction with care.

Two other trials ${ }^{28,30}$ compared proportion of satisfied patients between the communication training and control groups and found no statistically significant differences between groups $(P>.05)$ with high satisfaction levels for both groups. Another trial ${ }^{33}$ investigated whether the intervention predicted patients' satisfaction with care and reported that communication training predicted higher satisfaction levels (odds ratio [OR], 0.7; 95\% CI, 0.5-1.0).

Pain and Disability. For pain and disability, pooling of 2 trials $^{31,38}(\mathrm{n}=971$ patients) provided small effects favoring the intervention compared to control at short-term follow-up (Fig 3). Weighted mean differences for pain and disability were, respectively, -3.8 points $(95 \% \mathrm{CI},-6.5$ to -1.1$)$ 


\begin{tabular}{|c|c|}
\hline Study name & $\begin{array}{l}\text { Difference in me } \\
\text { and } 95 \% \mathrm{Cl}\end{array}$ \\
\hline \multicolumn{2}{|l|}{ Patients' satisfaction with care } \\
\hline Alder et al $2007^{27}$ & $3.5(-0.3$ to 7.3$)$ \\
\hline Bernhard et al $2011 a^{20}$ & $0.0(-2.1$ to 2.1$)$ \\
\hline Bernhard et al $2011 b^{20}$ & 5.8 (3.4 to 8.2$)$ \\
\hline Bieber et al $2008^{28}$ & $14.0(8.0$ to 20.0$)$ \\
\hline Brown et al $1999^{18}$ & $-0.5(-1.9$ to 0.9$)$ \\
\hline Edwards et al $2004^{15}$ & $-0.6(-2.5$ to 1.3$)$ \\
\hline Evans et al $1987^{32}$ & $15.4(13.8$ to 17.0$)$ \\
\hline Haskard et al $2008^{19}$ & $3.0(-2.0$ to 8.0$)$ \\
\hline Jensen et al $2011^{16}$ & $2.7(-2.3$ to 7.7$)$ \\
\hline Kennedy et al $2004^{26}$ & 3.7 (1.6 to 5.8$)$ \\
\hline Lewis et al $1991^{34}$ & $5.0(0.6$ to 9.4$)$ \\
\hline Loh et al $2007^{35}$ & $11.2(7.6$ to 14.8$)$ \\
\hline Sheffer $1999^{36}$ & $-1.8(-6.5$ to 2.9$)$ \\
\hline Shilling et al $2003^{37}$ & $0.1(-0.8$ to 1.0$)$ \\
\hline Suarez-Almazor et al $2010^{38}$ & $2.4(-2.6$ to 7.4$)$ \\
\hline Wetzels et al $2005^{17}$ & $2.3(-2.2$ to 6.8$)$ \\
\hline TOTAL; $I^{2}=0.0 \%$ (random effects); $P=.006$ & $4.1(1.1$ to 7.0$)$ \\
\hline
\end{tabular}

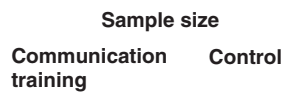

Difference in means and $95 \% \mathrm{Cl}$

Relative training

64
196
149
44
32
136
200
34
28
260
81
128
25
439
75
121
2012

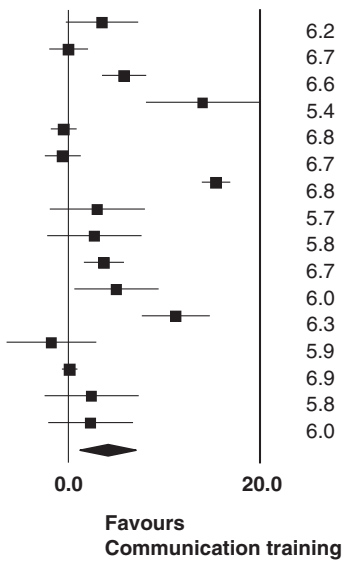

Fig 2. Pooled results for patients' satisfaction with care (communication training vs control). Right side favors the intervention.

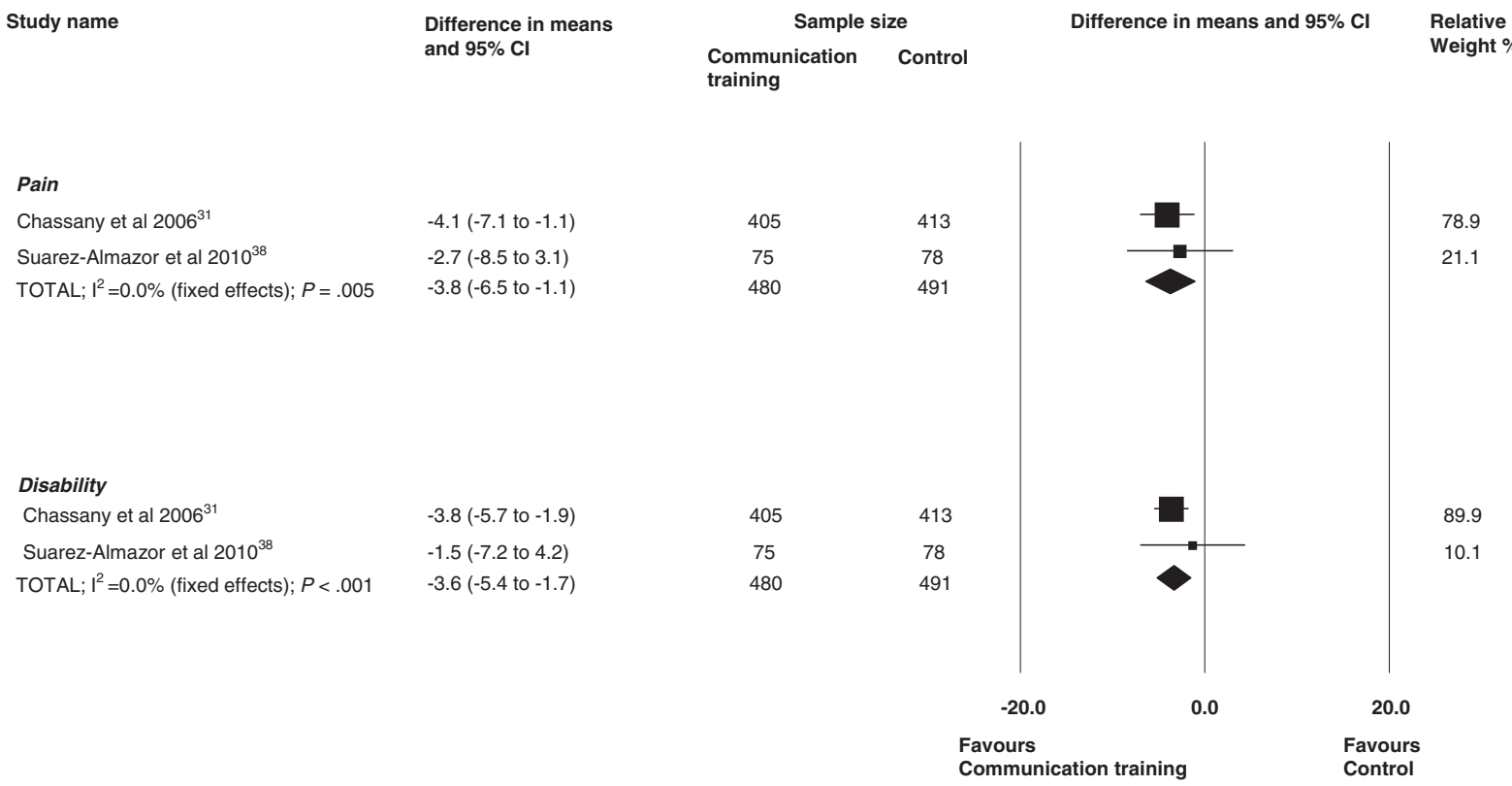

Fig 3. Pooled results for pain and disability (communication training vs control). Left side favors the intervention.

and -3.6 (95\% CI, -5.4 to -1.7$)$ on a 100 -point scale. Based on the GRADE system, there is moderate-quality evidence that communication training for clinicians has small effects on pain and disability when compared to control interventions.

\section{DISCUSSION}

Communication training for clinicians has been advocated to improve clinical outcomes in primary care and rehabilitation settings. ${ }^{2-4,11,12}$ Nevertheless, this review provides evidence that the effects of communication training for clinicians on patients' clinical outcomes were small. ${ }^{22}$ Training that emphasizes patients' participation showed effects across comparisons, which were statistically significant, although smaller than 5 points on a 100-point scale for satisfaction with care, pain, and disability. Current evidence shows that further research is very likely to have an important impact on our confidence in the estimate for patents' satisfaction with care and is likely to have an impact on our confidence in the estimate for pain and disability. Arguably, the small effects of communication training may be additional to specific effects of treatment rituals designed to decrease, for instance, pain and 


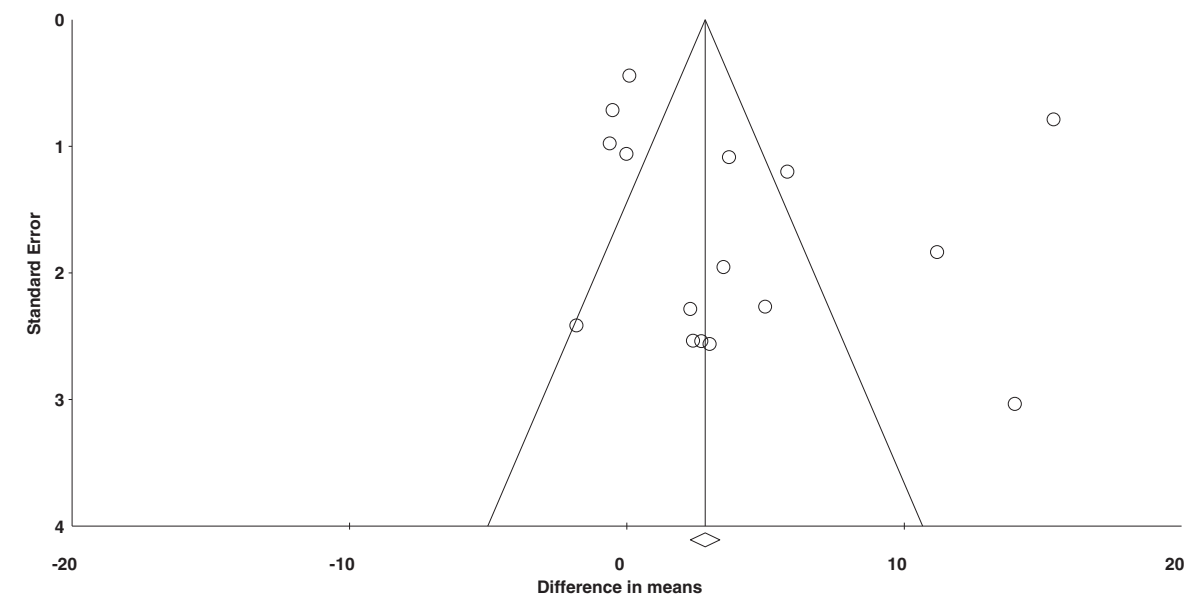

Fig 4. Funnel plot of SE by difference in means for the outcome patients' satisfaction with care $(n=16)$.

disability. ${ }^{39}$ However, whether the additional effect provided by training clinicians' communication skills justifies the costs incurred with its implementation is still debatable.

A previous review ${ }^{11}$ in the field of oncology showed small effects ${ }^{40}$ favoring communication training compared to control interventions on satisfaction with care (ie, most standardized mean differences were $<0.20$, ranging from 0.07 to 0.70 ). Our results were consistent with evidence in oncology and suggest that current communication training effects are small for satisfaction with care, pain, and disability in primary care and rehabilitation settings. Interestingly, another review ${ }^{12}$ including nonrandomized trials showed moderate effects of communication training on clinicians' communication skills (standardized mean difference of $0.54 ; 95 \%$ CI, 0.27-0.81); however, no significant effects were found on clinical outcomes. Hence, although communication training seems to be effective for changing clinicians' communication skills, it has only small effects on the patients' outcomes investigated in our review. This is the first systematic review to investigate the effectiveness of communication training for clinicians that included only randomized controlled trials in primary care and rehabilitation settings. We believe that our review provides the best available evidence to guide clinicians in primary care and rehabilitation settings, including allied health professionals.

Communication training for clinicians has moderate effects on clinicians' communication skills, ${ }^{12}$ although our findings suggest that it is a long way from communication training to shifts in improvements in communication skills and then changes in patients' outcomes. The pathway or processes including variables that are thought to be intermediate or mediators in the pathway toward outcomes are complex, and patients' outcomes may not be the best benchmarks to investigate the effectiveness of communication training for clinicians. The effect of an appropriate interaction might facilitate active treatments for complex conditions such as low back pain to reach the smallest worthwhile effects. ${ }^{41}$ For instance, where exercise reduces pain by 14.0 points $(95 \% \mathrm{CI}$,
6.0-21.0) on a 100-point scale in a typical patient with chronic low back pain, we argue that, with the additional effect of an improved patient-clinician interaction, the treatment benefits of exercise could reach the threshold considered by patients as being the smallest worthwhile effect for low back pain. Patients with chronic low back pain need to see on average 19.0 points $(\mathrm{SD}, 18)$ reduction in pain on a 100-point scale to consider exercise worthwhile. $^{42}$

There is limited evidence concerning the quality of frameworks in general underpinning communication training for clinicians, and those engaged in training have to rely on these limited resources. Arguably, specific verbal and nonverbal skills during patient-clinician interaction might impact on the effectiveness of communication training. Rapport building, up-front collaborative agenda setting, and acknowledging social and emotional concerns have emerged as potential domains to improve quality of care and efficiency. 43 For instance, emotional support (eg, length of consultation, interest, and caring) has consistently been associated with therapeutic alliance ${ }^{44}$ and clinical outcomes ${ }^{8}$ and might be a specific skill to focus on. Our research group has conducted a systematic review to investigate the verbal and nonverbal factors and interaction styles associated with satisfaction with care. ${ }^{8} \mathrm{We}$ found that some verbal and nonverbal factors concerning emotional support were consistently associated with higher levels of satisfaction with care (ie, most correlation values ranged from 0.21 to 0.41 ). Further research exploring potentially communication skills likely to impact on clinical outcomes is recommended. It remains unclear which specific communication skills should be addressed during communication skills training for clinicians.

A challenge in designing effective training for clinicians is the possibility of ceiling effects of communication skills. Many clinicians may already have adequate communication skills, and large improvements are unlikely to be achieved. This raises the question of indicators for training and whether there are clinicians with certain skills who would benefit most from these interventions. 


\section{LIMITATIONS AND FUtURE StUdiES}

A limitation that we faced in the present review was the heterogeneity in the measurement of satisfaction with care. A potential explanation for that heterogeneity is the different measurement instruments to capture patients' satisfaction with care used in the included trials. Moreover, these different measurement instruments may assess different aspects of satisfaction with care, such as patients' satisfaction with communication or with decision making. ${ }^{18,20}$ This problem was reported by previous studies ${ }^{8,11}$; however, the problem persists. To analyze effects of clinicians' communication training on the broad outcome patients' satisfaction with care described by the World Health Organization ${ }^{13}$ and reported in the literature, ${ }^{8,11,12}$ we transformed extracted data to a common 100-point scale and pooled them using random-effects model. That is recommended by the Cochrane Collaboration handbook to minimize heterogeneity among trials. ${ }^{21}$ Further limitations of the evidence include the methodological flaws of included trials. For instance, common problems included lack of concealed allocation, lack of similarity of groups at baseline, lack of blinding, dropouts more than 15\%, and not reporting analyses by intention to treat. All these methodological flaws can potentially introduce confounding bias. Future trials should address these methodological flaws. In addition, few trials investigated the effectiveness of communication training for clinicians on the patients' outcomes of pain and disability, and its current evidence is limited.

Further investigation on specific communication skills that may influence the effects of communication training is warranted. In addition, further research should investigate whether communication training for clinicians is effective on other outcomes such as rehabilitation programs adherence. We caution that it would be premature to remove communication training from the curricula for clinicians in primary care and rehabilitation settings.

\section{CONCLUSION}

This study found that communication training for clinicians has small effects on patients' satisfaction with care, pain, and disability. The current size of training effects on the investigated patients' clinical outcomes challenges investing in the currently proposed clinicians' communication training methods to improve patients' clinical outcomes.

\section{Funding SOURCES ANd Potential Conflicts of INTEREST}

No funding sources or conflicts of interest were reported for this study.

\section{CONTRIBUTORSHIP INFORMATION}

Concept development (provided idea for the research): V.C.O., M.L.F., K.R., P.H.F.
Design (planned the methods to generate the results): V.C.O., M.L.F., R.F.F., K.R., P.H.F.

Supervision (provided oversight, responsible for organization and implementation, writing of the manuscript): V.C.O., M.L.F., K.R., P.H.F.

Data collection/processing (responsible for experiments, patient management, organization, or reporting data): V.C.O., R.Z.P., R.F.F.

Analysis/interpretation (responsible for statistical analysis, evaluation, and presentation of the results): V.C.O., M.L.F., R.Z.P., R.F.F., K.R., P.H.F.

Literature search (performed the literature search): V.C.O., R.Z.P., R.F.F.

Writing (responsible for writing a substantive part of the manuscript): V.C.O., M.L.F., R.Z.P., R.F.F., K.R., P.H.F. Critical review (revised manuscript for intellectual content, this does not relate to spelling and grammar checking): V.C.O., M.L.F., R.Z.P., R.F.F., K.R., P.H.F.

\section{Practical Applications}

- This was the first systematic review to investigate the effectiveness of communication training for clinicians that included only randomized controlled trials in primary care and rehabilitation settings.

- Findings provided evidence that the effects of communication training for clinicians are small on patients' satisfaction with care, pain, and disability.

- Size of training effects on the investigated patients' clinical outcomes challenges investing in the currently proposed clinicians' communication training to improve patients' clinical outcomes.

\section{REFERENCES}

1. Payton OD. Effects of instruction in basic communication skills on physical therapists and physical therapy students. Phys Ther 1983;63:1292-7.

2. Abdel-Tawab N, Roter D. The relevance of client-centered communication to family planning settings in developing countries: lessons from the Egyptian experience. Soc Sci Med 2002;54:1357-68.

3. Towle A, Godolphin W. Framework for teaching and learning informed shared decision making. BMJ 1999;319:766-71.

4. Parry R. Are interventions to enhance communication performance in allied health professionals effective, and how should they be delivered? Direct and indirect evidence. Patient Educ Couns 2008;73:186-95.

5. McGilton KS, Boscart V, Fox M, Sidani S, Rochon E, SorinPeters R. A systematic review of the effectiveness of communication interventions for health care providers caring for patients in residential care settings. Worldviews Evid Based Nurs 2009;6:149-59.

6. Dibbelt S, Schaidhammer M, Fleischer C, Greitemann B. Patient-doctor interaction in rehabilitation: the relationship 
between perceived interaction quality and long-term treatment results. Patient Educ Couns 2009;76:328-35.

7. Stewart MA. Effective physician-patient communication and health outcomes: a review. CMAJ 1995;152:1423-33.

8. Oliveira VC, Refshauge KM, Ferreira ML, et al. Communication that values patients' autonomy is associated with satisfaction with care: a systematic review. J Physiother 2012;58:215-29.

9. Shaw WS, Pransky G, Roter DL, Winters T, Tveito TH, Larson SM. The effects of patient-provider communication on 3-month recovery from acute low back pain. J Am Board Fam Med 2011;24:16-25.

10. Ferreira PH, Ferreira ML, Maher CG, Refshauge KM, Latimer J, Adams RD. The therapeutic alliance between clinicians and patients predicts outcome in chronic low back pain. Phys Ther 2013;93:470-8.

11. Uitterhoeve RJ, Bensing JM, Grol RP, Demulder PH, Van Achterberg T. The effect of communication skills training on patient outcomes in cancer care: a systematic review of the literature. Eur J Cancer Care (Engl) 2010;19:442-57.

12. Barth J, Lannen P. Efficacy of communication skills training courses in oncology: a systematic review and meta-analysis. Ann Oncol 2011;22:1030-40.

13. WHO. Constitution of the World Health Organization. Am J Public Health 1946;36:1315-23.

14. Maher CG, Sherrington C, Herbert RD, Moseley AM, Elkins M. Reliability of the PEDro scale for rating quality of randomized controlled trials. Phys Ther 2003;83:713-21.

15. Edwards A, Elwyn G, Hood K, et al. Patient-based outcome results from a cluster randomized trial of shared decision making skill development and use of risk communication aids in general practice. Fam Pract 2004;21:347-54.

16. Jensen BF, Gulbrandsen P, Dahl FA, Krupat E, Frankel RM, Finset A. Effectiveness of a short course in clinical communication skills for hospital doctors: results of a crossover randomized controlled trial. Patient Educ Couns 2011;84:163-9.

17. Wetzels R, Wensing M, Van Weel C, Grol R. A consultation leaflet to improve an older patient's involvement in general practice care: a randomized trial. Health Expect 2005;8:286-94.

18. Brown JB, Boles M, Mullooly JP, Levinson W. Effect of clinician communication skills training on patient satisfaction. A randomized, controlled trial. Ann Intern Med 1999;131:822-9.

19. Haskard KB, White MK, Williams SL, DiMatteo MR, Rosenthal R, Goldstein MG. Physician and patient communication training in primary care: effects on participation and satisfaction. Health Psychol 2008;27:513-22.

20. Bernhard J, Butow P, Aldridge J, Juraskova I, Ribi K, Brown R. Communication about standard treatment options and clinical trials: can we teach doctors new skills to improve patient outcomes? Psychooncology 2012;21:1265-74.

21. Higgins J, Green S. Cochrane Handbook for Systematic Reviews of Interventions Version 5.1.0 [updated March 2011]. The Cochrane Collaboration; 2011. [Available from www.cochrane-handbook.org on 15 November 2012].

22. Chou R, Qaseem A, Snow V, et al. Diagnosis and treatment of low back pain: a joint clinical practice guideline from the American College of Physicians and the American Pain Society. Ann Intern Med 2007;147:478-91.

23. Guyatt G, Oxman AD, Akl EA, et al. GRADE guidelines: 1. Introduction-GRADE evidence profiles and summary of findings tables. J Clin Epidemiol 2011;64:383-94.

24. Oliveira VC, Ferreira PH, Maher CG, Pinto RZ, Refshauge KM, Ferreira ML. Effectiveness of self-management of low back pain: systematic review with meta-analysis. Arthritis Care Res (Hoboken) 2012;64:1739-48.

25. Ioannidis JP, Trikalinos TA. The appropriateness of asymmetry tests for publication bias in meta-analyses: a large survey. CMAJ 2007;176:1091-6.
26. Kennedy AP, Nelson E, Reeves D, et al. A randomised controlled trial to assess the effectiveness and cost of a patient orientated self management approach to chronic inflammatory bowel disease. Gut 2004;53:1639-45.

27. Alder J, Christen R, Zemp E, Bitzer J. Communication skills training in obstetrics and gynaecology: whom should we train? A randomized controlled trial. Arch Gynecol Obstet 2007;276:605-12.

28. Ammentorp J, Sabroe S, Kofoed P, Mainz J. Effects of a communication course for clinicians on parents' perception of care-a randomized controlled trial. Scand J Caring Sci 2009; 23:506-17.

29. Bieber C, Muller KG, Blumenstiel K, et al. A shared decisionmaking communication training program for physicians treating fibromyalgia patients: effects of a randomized controlled trial. J Psychosom Res 2008;64:13-20.

30. Cals JWL, Butler CC, Hopstaken RM, Hood K, Dinant G-J. Effect of point of care testing for $\mathrm{C}$ reactive protein and training in communication skills on antibiotic use in lower respiratory tract infections: cluster randomised trial. BMJ 2009;338:b1374.

31. Chassany O, Boureau F, Liard F, et al. Effects of training on general practitioners' management of pain in osteoarthritis: a randomized multicenter study. J Rheumatol 2006;33:1827-34.

32. Evans BJ, Kiellerup F, Stanley R, et al. A communication skills programme for increasing patients' satisfaction with general practice consultations. Br J Med Psychol 1987;60:373-8.

33. Frostholm L, Fink $P$, Oernboel E, et al. The uncertain consultation and patient satisfaction: the impact of patients' illness perceptions and a randomized controlled trial on the training of physicians' communication skills. Psychosom Med 2005;67:897-905.

34. Lewis CC, Pantell RH, Sharp L. Increasing patient knowledge, satisfaction, and involvement: randomized trial of a communication intervention. Pediatrics 1991;88:351-8.

35. Loh A, Simon D, Wills CE, Kriston L, Niebling W, Harter M. The effects of a shared decision-making intervention in primary care of depression: a cluster-randomized controlled trial. Patient Educ Couns 2007;67:324-32.

36. Sheffer SM. Effects of encounters with patient instructors, patient satisfaction \& physicians' interpersonal skills: Loyola U Chicago, US; 1999.

37. Shilling V, Jenkins V, Fallowfield L. Factors affecting patient and clinician satisfaction with the clinical consultation: can communication skills training for clinicians improve satisfaction? Psychooncology 2003;12:599-611.

38. Suarez-Almazor ME, Looney C, Liu Y, et al. A randomized controlled trial of acupuncture for osteoarthritis of the knee: effects of patient-provider communication. Arthritis Care Res 2010;62:1229-36.

39. Donovan HS, Kwekkeboom KL, Rosenzweig MQ, Ward SE. Nonspecific effects in psychoeducational intervention research. West J Nurs Res 2009;31:983-98.

40. Cohen J. A power primer. Psychol Bull 1992;112:155-9.

41. Ferreira ML, Herbert RD, Ferreira PH, et al. A critical review of methods used to determine the smallest worthwhile effect of interventions for low back pain. J Clin Epidemiol 2012;65:253-61.

42. Ferreira M, Ferreira PH, Latimer J, et al. Consumer's perceptions of the smallest worthwhile effect of interventions for non-specific low back pain. World Physical Therapy. Netherlands: Physiotherapy; 2011eS479.

43. Mauksch LB, Dugdale DC, Dodson S, Epstein R. Relationship, communication, and efficiency in the medical encounter - creating a clinical model from a literature review. Arch Intern Med 2008; 168:1387-95.

44. Pinto RZ, Ferreira ML, Oliveira VC, et al. Patient-centered communication is associated with positive therapeutic alliance: a systematic review. J Physiol Lond 2012;58:77-87. 


\section{Appendix A. Search Strategy Conducted on November 10, 2012, and Updated on June I, 2015}

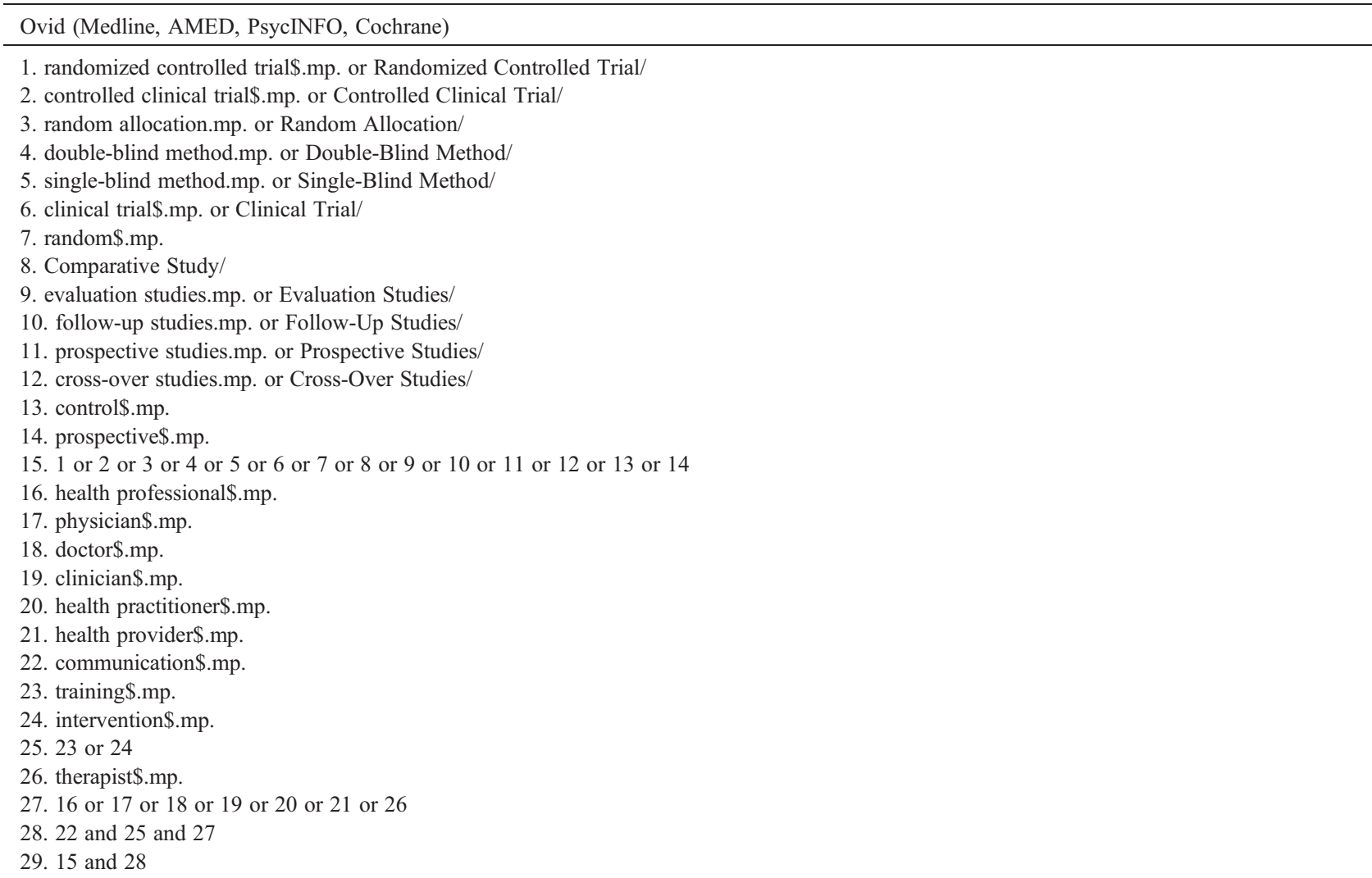

\section{Ebsco (CINAHL)}

S1. double blind studies

S2. single blind studies

S3. clinical trials

S4. ("placebo\$") or (MH "Placebos")

S5. (MH "Study Design+") or (MH "Experimental Studies+")

S6. (MH "Comparative Studies") or (MH "Multicenter Studies") or (MH "Multimethod Studies")

S7. (MH "Prospective Studies+") or (MH "Concurrent Prospective Studies")

S8. "random"

$\mathrm{S} 9 . \mathrm{S} 1$ or $\mathrm{S} 2$ or $\mathrm{S} 3$ or $\mathrm{S} 4$ or $\mathrm{S} 5$ or $\mathrm{S} 6$ or $\mathrm{S} 7$ or $\mathrm{S} 8$

S10. ("Therapist\$") or (MH "Australian Association of Occupational Therapists") or (MH "Massage Therapists") or (MH "Recreational Therapists") or (MH "Respiratory Therapists") or (MH "Occupational Therapist Attitudes") or (MH "Physical Therapist Attitudes") or (MH "Respiratory Therapist Attitudes") or (MH "British Association and College of Occupational Therapists") or (MH "Canadian Association of Occupational Therapists")

S11. ("Health Professional\$") or (MH "Traveling Health Professionals") or (MH "Impairment, Health Professional") or (MH "Health Professional, Disabled+") or (MH "Health Personnel as Patients+") or (MH "Health Personnel, Infected") or (MH "Health Personnel, Minority+") or (MH "Multiskilled Health Practitioners") or (MH "Disease Transmission, Professional-to-Patient") or (MH "Foreign Professional Personnel+")

S12. ("Physician\$") or (MH "Physician's Role") or (MH "Physicians, Emergency") or (MH "Physicians, Family") or (MH "Physicians, Sports Team") or (MH "Physicians, Women") or (MH "American College of Emergency Physicians") or (MH "Physicians+") or (MH "Education, Physician Assistants") or (MH "Physician Assistants")

S13. ("Doctor\$") or (MH "Doctorally Prepared Nurses") or (MH "Education, Doctoral+") or (MH "Education, Nursing, Doctoral") or (MH "Education, Nursing, Post-Doctoral") or (MH "Education, Post-Doctoral+") or (MH "Students, Nursing, Doctoral") or (MH "Chiropractors") or (MH "Physicians+") or (MH "Physicians, Family")

S14. ("Clinician\$") or (MH "Expert Clinicians+") or (MH "Novice Clinicians+") or (MH "Clinical Nurse Specialists") or (MH "Decision Support Systems, Clinical")

S15. ("Health Practitioner\$") or (MH "Multiskilled Health Practitioners") or (MH "National Association of Nurse Practitioners in Reproductive Health") or (MH "Community Practitioners' and Health Visitors' Association") or (MH "Alternative Health Personnel+") or (MH "Rural Health Personnel")

S16. ("Health Care Provider\$") or (MH "Child Care Providers") or (MH "Health Care Delivery+") or (MH "Health Care Delivery, Integrated") or (MH "Health Care Errors+") or (MH "Health Care Reform") 
(continued)

Ovid (Medline, AMED, PsycINFO, Cochrane)

$\mathrm{S} 18 . \mathrm{S} 10$ or $\mathrm{S} 11$ or $\mathrm{S} 12$ or $\mathrm{S} 13$ or $\mathrm{S} 14$ or $\mathrm{S} 15$ or $\mathrm{S} 16$ or $\mathrm{S} 17$

S19. ("Communication\$") or (MH "Communications Media+") or (MH "Nonverbal Communication+") or (MH "Communication Barriers")

S20. Training

S21. "intervention"

$\mathrm{S} 22$. S20 or S21

S23. S18 and S19 and S22

S24. S9 and S23

\section{PEDro}

Title and abstract: communication

Therapy: no selection

Problem: no selection

Body part: no selection

Subdiscipline: no selection

Method: clinical trial

\section{Embase}

16. \#12 AND \#15

15. \#14 NOT \#13

14. \#1 OR \#2 OR \#3 OR \#4 OR \#5 OR \#6 OR \#7 OR \#8

13. 'animal' OR 'animal'/exp OR animal

12. \#9 AND \#10 AND \#11

11. 'training'/exp OR 'training' OR 'intervention'

10. 'communication'/exp OR communication

9. 'therapist' OR 'health professional'/exp OR 'health professional' OR 'physician'/exp OR 'physician' OR 'doctor'/exp OR 'doctor' OR 'clinician'

OR 'health practitioner'/exp OR 'health practitioner' OR 'health provider'

8. random\$

7. clinical AND trial\$.

6. 'single blind' AND ('method'/exp OR method)

5. 'double blind' AND ('method'/exp OR method)

4. random AND allocation

3. randomised AND controlled AND trial\$

2. controlled AND clinical AND trial

1. randomized AND controlled AND trial 
Appendix B. Transformed Data and Imputations for Included Trials

\begin{tabular}{|c|c|c|c|c|c|c|}
\hline \multirow[b]{2}{*}{ Study } & \multicolumn{3}{|c|}{ Communication Training } & \multicolumn{3}{|c|}{ Control } \\
\hline & Mean & $\mathrm{SD}$ & Sample & Mean & $\mathrm{SD}$ & Sample \\
\hline \multicolumn{7}{|c|}{ Satisfaction with care (transformed to $0-100$ scale) } \\
\hline Alder et al $2007^{27}$ & 60.8 & 12.3 & 64 & 57.3 & 9.7 & 64 \\
\hline Bernhard et al $2011 \mathrm{a}^{20, \mathrm{a}, \mathrm{b}}$ & 59.6 & 10.5 & 196 & 59.6 & 10.5 & 194 \\
\hline Bernhard et al $2011 b^{20, a, b}$ & 71.2 & 10.5 & 149 & 65.4 & 10.5 & 155 \\
\hline Bieber et al $2008^{28}$ & 84.0 & 14.0 & 44 & 70.0 & 14.0 & 41 \\
\hline Brown et al $1999^{18, \text { a }}$ & 0 & 2.8 & 32 & 0.5 & 2.8 & 29 \\
\hline Edwards et al $2004^{15, c}$ & -0.6 & 8.7 & 136 & 0.0 & 8.7 & 186 \\
\hline Evans et al $1987^{32}$ & 99.3 & 3.9 & 200 & 83.9 & 10.5 & 200 \\
\hline Haskard et al $2008^{19, \text { a }}$ & 91.0 & 10.5 & 34 & 88.0 & 10.5 & 33 \\
\hline Jensen et al $2011^{16, c}$ & 2.7 & 9.6 & 28 & 0.0 & 9.6 & 29 \\
\hline Kennedy et al $2004^{26}$ & 71.9 & 13.2 & 260 & 68.2 & 13.5 & 358 \\
\hline Lewis et al $1991^{34}$ & 82.5 & 13.0 & 81 & 77.5 & 12.8 & 54 \\
\hline Loh et al $2007^{35}$ & 91.2 & 10.8 & 128 & 80.0 & 14.4 & 66 \\
\hline Sheffer $1999^{36}$ & 84.3 & 9.1 & 25 & 86.1 & 7.5 & 23 \\
\hline Shilling et al $2003^{37}$ & 96.8 & 6.7 & 439 & 96.7 & 6.4 & 422 \\
\hline Suarez-Almazor et al $2010^{38}$ & 82.6 & 15.6 & 75 & 80.2 & 15.8 & 78 \\
\hline Wetzels et al $2005^{17, c}$ & 2.3 & 18.5 & 121 & 0.0 & 18.5 & 142 \\
\hline \multicolumn{7}{|c|}{ Pain (transformed to $0-100$ scale) } \\
\hline Chassany et al $2006^{31}$ & -28.7 & 22.9 & 405 & -24.6 & 20.9 & 413 \\
\hline Suarez-Almazor et al $2010^{38}$ & 27.0 & 17.9 & 75 & 29.7 & 18.7 & 78 \\
\hline \multicolumn{7}{|c|}{ Disability (transformed to $0-100$ scale) } \\
\hline Chassany et al $2006^{31}$ & -13.3 & 15.3 & 405 & -9.5 & 12.6 & 413 \\
\hline Suarez-Almazor et al $2010^{38}$ & 29.7 & 18.0 & 75 & 31.2 & 18.2 & 78 \\
\hline
\end{tabular}

$S D$, standard deviation.

${ }^{\text {a }} \mathrm{SD}$ estimated based on average SD of other included trials.

${ }^{b}$ Investigated effects in 2 different settings separately.

${ }^{c}$ SD estimated based on confidence intervals. 